\title{
AFLATOXIGENICITY OF A.flavus ISOLATED FROM PHYLLOSPHERE OF BANANA PLANT
}

\section{MANISH KUMAR ${ }^{1}$}

Department of Botany, Lalit Narayan Mithilla University, Darbhanga, Bihar, India

\begin{abstract}
Aflatoxins are toxic metabolities produced by certain fungi in/on foods and feeds.They are the best known and most intensively researched mycotoxins. The occurrence of Aflatoxins is influenced by certain environmental factors; hence the extent of contamination varies with geographic location, agricultural and agronomic practices, and the susceptibility of commodities of fungal invasion during pre-harvest, storage and/or processing periods. Aflatoxins have received greater attention than any other mycotoxins because of their demonstrated potent carcinogenic effect in susceptible laboratory animals and their acute toxicological effects in humans.
\end{abstract}

KEYWORDS: Aspergillus flavus, Aflatoxin, Phyllosphere, Banana

Aflatoxin is a mycotoxin produced by the members of Aspergillus flavus group (Raper and Fennell, 1965) of fungi (Kulik and Holaday, 1966). Among the A.flavus group, A.flavus link and A.parasiticus species are the most active aflatoxin producers (Hesseltine et al, 1966). Their presence in the phylloplane of papaya (Prasad, 1976), Banana (Jha, 1977), leaves as well as in the aeromycosporal complex of grain godowns of Bairginia (Prasad, 1992) and aerospora of Samastipur (Roy, 1993) and Bhagalpur (Ghani, 1994) in Bihar and Gulberga (Murlimanohar and Reddi, 1995) of Bhilai (M.P), (Shahu, 1996) have been extensively studied and their results further confirm the present observation that A.flavus isolates were more potent among the 51 other isolates of Aspergillus species encounterd in the phyllosphere of Banana (Var., Malbhog) plant during the present investigation. Therefore, the Aflatoxin producing potency was evaluated to highlight the gravity of situation of high incidence of $A$. flavus isolates in phylloplane of banana plant and their Aflatoxigenic potency.

\section{MATERIALS AND METHODS}

For the purpose of screening of Aflatoxigenic isolates, individual isolates were inoculated in a culture flask containing liquid rice flour medium and were allowed to incubate for 10 days at room temperature $\left(28^{\circ} \pm 2^{\circ} \mathrm{c}\right)$. The inoculated flasks were daily shaken for $1 / 2$ hour manually or on a wrist action electric shaker. At the end of incubation period the culture filtrates were collected after harvesting the mycelia mats over whatman filter paper no. $1.5 .0 \mathrm{ml}$ of the culture filtrates were taken in separating funnel $(250 \mathrm{ml})$ and were added with $25 \mathrm{ml}$ of chloroform. The mixtures were thoroughly shaken for 20 minutes after which the clear lower aliquots were allowed to pass through a bed of anhydrous sodium sulphate kept on the filter paper. The sodium sulphate was rewashed with $10 \mathrm{ml}$. chloroform.

For the estimation of Aflatoxins, T.L.C. technique was applied. The solvents were allowed to run upto $15 \mathrm{~cm}$ in vertical direction after which the plates were taken out of the chromatography tank and air dried in a dust free condition. The plates were later observed under long wave UV- lamp (365nm) in complete darkness for the spot of Aflatoxin. The confirmation of Aflatoxins were done by the derivative formation with TFA (Tri fluro acitic acid) as suggested by Stack and Pohland (1975).

\section{RESULTS AND DISCUSSION}

The Aspergilli Constitute a major component of the aerobiota especially around the Banana field, of which some eleven species were found associated with the Phylloplane mycoflora of this plant. The secondary metabolite of $A$. flavus is well known for its toxigenic ,teratogenic and carcinogenic potency. In total 51 A.flavus isolates were collected of which 12 were found to be Aflatoxigenic in nature (i.e $23.4 \%$ of the total). Among Aspergilli, A. niger, A. flavus, A. fumigatus and A. terreus are well known toxigenic as well as allergenic forms and if such forms dominate in the aerospora then there may be greater possibility of Aflatoxicosis of lungs to the human beings living around the orchard.

\footnotetext{
${ }^{1}$ Corresponding author
} 
On the basis of present findings it can be said that the incidence of toxigenic isolates are more frequent on the nature of agricultural commodities including fruit and vegetables. However, the frequency of appearance may vary in different geographic regions during varying climatic conditions. Table 1 and Table 2 have shown the screening of several isolates collected from leaf surface of banana and quantitative production of Aflatoxin from A.flavus respectively.

Table 1: Showing screening of Aspergillus flavus isolates collected from leaf surface of banana during different months for their toxigenic potentialities on RFM media in 11 days of incubation at room temperature $\left(24^{\circ} \pm 2^{\circ} \mathrm{C}\right)$

\begin{tabular}{|c|cc|c|}
\hline Sr. No. & Isolates of the months & $\begin{array}{c}\text { Presence or absence of toxin on RFM } \\
\text { medium }\end{array}$ \\
\hline 1 & A.f. Jan - (1-3) 3 isolates & - \\
\hline 2 & A.f Feb - $(4-7) \quad 4$ isolates & - \\
\hline 3 & A.f March - (8-9) 2 isolates & ++ \\
\hline 4 & A.f April - $(10-15) 6$ isolates & ++++ \\
\hline 5 & A.f May - $(16-19) 4$ isolates & ++++ \\
\hline 6 & A.f June - $(20-24) 5$ isolates & ++ \\
\hline 7 & A.f July - $(25-31) 7$ isolates & ++ \\
\hline 8 & A.f Nov. - $(32-42) 11$ isolates & ++ \\
\hline 9 & A.f Dec. - $(43-51) 9$ isolates & + \\
\hline
\end{tabular}

Total isolates: 51, RFM: Rice flour medium (Misra \& Sinha, 1979)

Table 2: Showing quantitative production of aflatoxin B1 and qualitative elaboration of other aflatoxins by the 12 toxigenic isolates of Aspergillus flavus collected from phyllosphere complex of Banana (malbhog variety) plant on RFM medium in 11 days of incubation at room temperature. $\left(24^{\circ} \pm 2^{\circ} \mathrm{C}\right)$

\begin{tabular}{|c|c|c|c|c|c|}
\hline Sr. No. & $\begin{array}{c}\text { Isolate No. (Month \& } \\
\text { Isolate no.) }\end{array}$ & $\begin{array}{c}\text { Quantity of aflatoxin } \\
\text { B1 } \mu \mathrm{g} / 25 \mathrm{ml} \text {. }\end{array}$ & $\mathbf{B}_{2}$ & $\mathbf{G}_{1}$ & $\mathbf{G}_{2}$ \\
\hline 1 & A.f. Ma. - 9 & $110.50 \quad \mu g$ & + & $\mathrm{t}$ & - \\
\hline 2 & A.f. Ap. - & $186.64 \mu \mathrm{g}$ & ++ & + & $\mathrm{t}$ \\
\hline 3 & A.f. Ap - & $180.88 \mu \mathrm{g}$ & ++ & - & - \\
\hline 4 & A.f. Ap. - & $206.30 \mu \mathrm{g}$ & ++ & + & - \\
\hline 5 & A.f. My. - & $247.30 \mu \mathrm{g}$ & ++ & ++ & + \\
\hline 6 & A.f. My. - & $218.84 \mu \mathrm{g}$ & ++ & + & $\mathrm{t}$ \\
\hline 7 & A.f. Jn. - & $198.62 \mu \mathrm{g}$ & ++ & $\mathrm{t}$ & - \\
\hline 8 & A.f. Jn. - & $210.50 \mu \mathrm{g}$ & ++ & ++ & + \\
\hline 9 & A.f. Jn. - & $194.46 \mu \mathrm{g}$ & - & + & - \\
\hline 10 & A.f. Jl. - & $102.60 \mu \mathrm{g}$ & - & + & - \\
\hline 11 & A.f. Nov. - & $93.30 \mu \mathrm{g}$ & ++ & + & $\mathrm{t}$ \\
\hline 12 & A.f. Dec. - & $82.85 \mu \mathrm{g}$ & ++ & + & - \\
\hline
\end{tabular}

Mean Average --- $169.482 \mu \mathrm{g}$

STASTISTICAL ANALYSIS OF TABLE

$\mathrm{SE}=0.1670$

$\mathrm{CD}= \pm 0.6399$ at $1 \%$ level of $\mathrm{P}$

Summary of statistical analysis:

Replicates - Non - Significant

Isolates - Highly Significant

\begin{tabular}{|c|c|}
\hline $\begin{array}{c}\text { Isolate No. (Month \& } \\
\text { Isolate no.) }\end{array}$ & $\begin{array}{c}\text { Quantity of aflatoxin } \\
\text { B1 } \boldsymbol{\mu} \mathbf{g} / \mathbf{2 5} \mathbf{~ m l} \text {. }\end{array}$ \\
\hline A.f. Ma. - 9 & $110.50 \mu \mathrm{g}$ \\
\hline
\end{tabular}

\begin{tabular}{|ll|l|}
\hline A.f. Ap. - & 11 & $186.64 \mu \mathrm{g}$ \\
\hline A.f. Ap - & 12 & $180.88 \mu \mathrm{g}$ \\
\hline A.f. Ap. - & 15 & $206.30 \mu \mathrm{g}$ \\
\hline A.f. My. - & 17 & $247.30 \mu \mathrm{g}$ \\
\hline A.f. My. - & 18 & $218.84 \mu \mathrm{g}$ \\
\hline A.f. Jn. - & 20 & $198.62 \mu \mathrm{g}$ \\
\hline A.f. Jn. - & 22 & $210.50 \mu \mathrm{g}$ \\
\hline A.f. Jn. - & 23 & $194.46 \mu \mathrm{g}$ \\
\hline A.f. Jl. - & 25 & $102.60 \mu \mathrm{g}$ \\
\hline A.f. Nov. - & 41 & $93.30 \mu \mathrm{g}$ \\
\hline A.f. Dec. - & 44 & $82.85 \mu \mathrm{g}$ \\
\hline
\end{tabular}




\section{KUMAR: AFLATOXIGENICITY OF A.flavus ISOLATED FROM PHYLLOSPHERE OF BANANA PLANT}

\section{REFERENCES}

Ghani J., 1994. Incidence of air borne fungi inside different Laboratories at Bhagalpur Ind. Jour. Aerobial, 7: 8-12.

Govan J.R., Hughes J.E. and Vandamme P., 1996. Burkholderia cepacia: medical, taxonomic and ecological issues. J. Med. Microbiol, 45: 395 407.

Jacobs J.L. and Sundin G.W., 2001. Effect of solar UV-B radiation on a Phyllosphere bacterial community. Appl. Environ. Microbiol, 67: 5488-5496.

Jha N.K., 1977. Investigations on fruit rot diseases of banana, Ph.D. thesis, L.N. Mithila University, DBG.

Kinkel L.L., 1997. Microbial population dynamics on leaves. Annu. Rev. Phytopathol, 35: 327-347.

Kulik Y.D. and Holaday C.E., 1966. Aflatoxin: a metabolic product of several fungi, Mycopathol.Mycol. Appl., 30: 137-402.

Mercier J. and Lindow S.E., 2000. Role of leaf surface sugars in colonization of Plants by bacterial epiphytes. Appl. Environ. Microbial., 66: 369374.

Morris C.E. and Kinkel L.L., 2002. Fifty years of phyllosphere microbiology: Significant contributions to research in related fields, p. $365-$ 375. In S.E. Lindow, E.I.Hecht - Poinar and
V.Elliott (ed.), Phyllosphere microbiology. APS Press, St. Paul, Minn.

Muralimohan G.U. and Reddy C.N., 1995. Occurrence of Aflatoxin, B1, and Aspergillus flavus in certain food and feed commodities marketed in gulberga city. Bull.Pure \& Appl. Sci., 14: 1-6.

Prasad J.S., 1976. Investigations on fruit rot diseases of Papaya in North Bihar, Ph.D. Thesis, L.N.M.U; Darbhanga, Bihar.

Prasad S.B., 1992. Ecology of toxigenic aeromycoflora of Bairginia, Ph.D. Thesis, L.N.M.U; Darbhanga.

Raper K.B. and Fennell D.I., 1965. The genus Aspergillus, the Williams \& Wilkins Co., Baltimore, PP 686.

Roy S.K., 1993. Ecotoxicological study of aeromycospora of Samastipur (N.B), Ph.D. Thesis, L.N.M.U., Darbhanga.

Sahu S.K., 1996. Studies on mycoflora associated with spinach. Ph.D. Thesis, Pt. Ravi Shanker Shukla, University, Rajpur, M.P.

Stack M.L. and Pohland A.E., 1975. Collaborative study of a method for chemical confirmation of the identity of Aflatoxin, J.A.O.A.C., 58: 110-115.

Sundin G.W., 2002. Ultraviolet radiation on leaves: Its influence on microbial communities and their adaptions, p. 27-42. In S.E. Lindow, E.I. Hecht Poinar and V. Elliott (ed.), Phyllosphere microbiology. APS Press, St. Paul, Minn. 